\title{
Effects of a Microcystis aeruginosa bloom and bacterivory on bacterial abundance and activity in a eutrophic reservoir
}

\author{
Karel Horňák ${ }^{1, *}$, Jan Jezbera' ${ }^{1}$, Karel Šimek ${ }^{1,2}$ \\ ${ }^{1}$ Biology Centre of the Academy of Sciences of the Czech Republic, v.v.i., Institute of Hydrobiology, Na Sádkách 7, \\ 37005 České Budějovice, Czech Republic \\ ${ }^{2}$ University of South Bohemia, Faculty of Science, Branišovská 31, 37005 České Budějovice, Czech Republic
}

\begin{abstract}
We investigated the changes in bacterioplankton abundance, composition, and fractions of cells incorporating leucine associated with a Microcystis aeruginosa bloom and enhanced protozoan grazing in a eutrophic reservoir. Bacterial community composition and leucine incorporation were studied by means of fluorescence in situ hybridization and microautoradiography. To alter the levels of protozoan grazing and the interactions of bacteria with the $M$. aeruginosa bloom, a manipulation experiment using size-fractionation and dialysis bag techniques was conducted. Samples collected from the Microcystis-poor dam area and the Microcystis-rich middle part of the reservoir were incubated as $<0.8 \mu \mathrm{m},<5 \mu \mathrm{m}$, and unfiltered treatments in dialysis bags at their collection sites and, in parallel, one of each of the treatments from one site was transferred to and incubated at the other site. The sample transfer from the dam to the middle part induced a decrease in abundances and doubling times of total bacteria, Betaproteobacteria, and of the R-BT065 cluster (a subgroup of Betaproteobacteria), whereas the transfer to the dam station revealed the opposite trends. In the presence of flagellates and the $M$. aeruginosa bloom, both abundance and fractions of cells incorporating leucine of Betaproteobacteria and of the R-BT065 cluster transferred to the middle station decreased dramatically, while members of the Sphingobacteria-Flavobacteria lineage became the dominant part of the community. While Gammaproteobacteria accounted for a minor proportion of the total community, their relative proportions and activity increased at the middle station, likely being stimulated by the increased resource availability.
\end{abstract}

KEY WORDS: Reservoir - Microcystis aeruginosa - Bacterial activity · Leucine incorporation · Protozoan grazing

Resale or republication not permitted without written consent of the publisher

\section{INTRODUCTION}

In eutrophic environments, massive cyanobacterial blooms frequently develop during summer, producing potentially toxic or noxious compounds and negatively affecting water quality (Chorus \& Bartram 1999). Effects of intense cyanobacterial blooms on bacteria are related mainly to the production of various organic compounds, representing an important source of dissolved organic carbon (DOC) for bacteria (Baines \& Pace 1991). The amount and nature of cyanobacterial exudates specifically influence bacterial growth and activity (e.g. Kirkwood et al. 2006), causing significant shifts in bacterial community composition (Christoffersen et al. 2002, Eiler \& Bertilsson 2004). In addition, production of allelopathic substances (Østensvik et al. 1998), competition for nutrients (e.g. Chorus \& Bartram 1999), zooplankton grazing (Gobler et al. 2007), or viral lysis (van Hannen et al. 1999) also influence the cyanobacteria-bacteria interactions.

Various cyanobacteria, e.g. some strains of Microcystis spp., are common producers of several classes of 
secondary metabolites, with microcystins (MCs) being the most frequently studied group of cyanotoxins (Codd 1995). The release of MCs depends on many factors, such as light and nutrient conditions, temperature, or physiological status (Park et al. 1998). Colonies of Microcystis spp. are often associated with heterotrophic bacteria (Worm \& Søndergaard 1998), constituting a significant portion of total bacterial abundance and production (Brunberg 1999). In contrast, growth and activity of bacterial assemblages not previously subjected to the specific cyanobacterial effects, e.g. various cyanotoxins, may be suppressed when exposed to Microcystis blooms.

Bacteria are also subjected to various mortality factors such as protistan (e.g. Pace 1988) and zooplankton grazing (Jürgens et al. 1994) and viral lysis (Weinbauer \& Höfle 1998). Predation by heterotrophic nanoflagellates (HNF) and cilates controls bacterial abundance, biomass, and production (e.g. Hahn \& Höfle 2001) and also induces significant changes in the bacterioplankton composition and cell-size structure, e.g. by selective ingestion of certain prey cells within the entire bacterial assemblage (e.g. Jezbera et al. 2006).

Capabilities of bacteria to incorporate various compounds substantially differ even at the group-specific level (e.g. Cottrell \& Kirchman 2000, Vila et al. 2004). Both relative abundance and activity of bacteria may be notably modified by changes in substrate concentration, bacterivory, or structure of dissolved organic matter (Alonso \& Pernthaler 2006, Horňák et al. 2006, Pérez \& Sommaruga 2006).

The purpose of this study was to examine the potential interactions between the summer bloom of Microcystis aeruginosa and in situ abundances and activity of major bacterioplankton groups in the eutrophic Římov reservoir (Czech Republic). Bacterial community composition in this model system is both seasonally and spatially dominated by Betaproteobacteria, namely by its R-BT065 cluster (subcluster of Rhodoferax sp. BAL47 lineage; Šimek et al. 2001, Zwart et al. 2002). The R-BT065 group represents the fastestgrowing part of the community and is likely responsible for the majority of production and activity processes in the reservoir (Horňák et al. 2006, Šimek et al. 2006). We hypothesized that bacterioplankton community dynamics are likely differently affected by pronounced differences in the development of an $M$. aeruginosa bloom at 2 stations (5 km apart) of the same canyon-shaped reservoir. Aspects that are most likely to be affected by the bloom are related to shifts in the bacterial community and its capabilities to take up organic substrates. Correspondingly, we focused on: (1) the influence of different $M$. aeruginosa bloom intensities in the dam area and the middle part of the reservoir on bacterial community composition and fractions of cells incorporating leucine, (2) the response of dominant groups of free-living bacterioplankton to different levels of protistan grazing and to the presence of $M$. aeruginosa, using the dialysis bag technique and sample transfers along the longitudinal axis of the reservoir.

\section{MATERIALS AND METHODS}

Sampling and field experiment. The experiment was carried out in the eutrophic canyon-shaped Římov reservoir (for details, see Šimek et al. 2006) during the summer phytoplankton maximum (18 to 22 August 2003) close to the dam of the reservoir (Stn Dam), and in the middle part of the reservoir (Stn Middle), where a heavy phytoplankton bloom, dominated by Microcystis aeruginosa, had developed. In brief, $\sim 40 \mathrm{l}$ of water were collected from each station from a depth of $0.5 \mathrm{~m}$. To alter the levels of bacterivory, the water was size-fractionated using 5 and $0.8 \mu \mathrm{m}$ polycarbonate filters (Poretics). The $<5 \mu \mathrm{m}$ treatment contained bacteria, HNF, and small algae, whereas zooplankton and ciliates were removed. The $<0.8 \mu \mathrm{m}$ treatment contained only bacteria, whereas all bacterivores were removed. Unfiltered water treatments containing bacteria, protists, zooplankton, and large colonies of $M$. aeruginosa were taken in parallel from each station. All size fractions $(<0.8 \mu \mathrm{m},<5 \mu \mathrm{m}$, and unfiltered treatments) were incubated in dialysis bags (each contain-

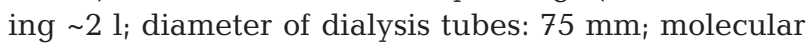
weight cutoff: 12 to $16 \mathrm{kDa}$; incubated 3 times in Milli$\mathrm{Q}$ water at $70^{\circ} \mathrm{C}$ for $30 \mathrm{~min}$ and washed with Milli-Q water; Spectrapore, Poly Labo). Samples from Stns Dam and Middle were incubated at their site of collection and, in parallel, one of each of the treatments from one site was transferred to and incubated at the other site, yielding 4 treatments (Dam in situ: $\mathrm{D}_{\text {; }}$ Dam transplanted to Middle: $\mathrm{D} \rightarrow \mathrm{M}_{i}$ Middle in situ: $\mathrm{M}_{i}$ and Middle transplanted to Dam: $\mathrm{M} \rightarrow \mathrm{D}$ ). All treatments were incubated in the reservoir in duplicates for $4 \mathrm{~d}$ at a depth of $0.5 \mathrm{~m}$. Samples for bacterial and HNF abundances and bacterial biomass and production were collected daily at $24 \mathrm{~h}$ intervals $\left(t_{0}, t_{24}, t_{48}, t_{72}\right.$, and $t_{96}$ ). Samples for protozoan grazing and fluorescence in situ hybridization (FISH) were sampled at $t_{0}, t_{48}$, and $t_{96}$. Samples for microautoradiography were taken at $t_{0}$ and $t_{96}$.

Phosphorus and chlorophyll a. Concentrations of total phosphorus (TP) and dissolved reactive phosphorus (DRP) were determined spectrophotometrically (Kopáãek \& Hejzlar 1993). Prior to analysis, samples were filtered through a $200 \mu \mathrm{m}$ mesh size filter. Samples for chlorophyll a (chl a) were filtered through Whatman GF/C filters, extracted in $90 \%$ acetone, and measured 
spectrophotometrically (Lorenzen 1967). Live and Lugols-preserved samples were analyzed for phytoplankton species composition by using light microscopy.

Bacterial abundance, biomass, and production. Samples of 1 to $2 \mathrm{ml}$ for bacterial abundance were fixed with $0.2 \mu \mathrm{m}$ prefiltered formaldehyde (final concentration $2 \%$ ), stained with DAPI (final concentration $1 \mu \mathrm{g} \mathrm{ml}^{-1}$ ), and concentrated on $0.2 \mu \mathrm{m}$ black polycarbonate filters (Poretics). Bacteria were enumerated using epifluorescence microscopy (BX-60, Olympus). At least 500 DAPI-stained cells were counted per sample. To determine bacterial cell size, between 500 and 800 DAPI-stained cells were recorded per sample at $1000 \times$ magnification with an analog monochrome camera (Cohu) and processed with the semiautomatic image analysis system LUCIA D (Laboratory Imaging). Bacterial biomass was calculated from the allometric relationship between bacterial volume and carbon cell content (Norland 1993). Bacterial production was measured by a thymidine incorporation method modified from Riemann \& Søndergaard (1986) as described by Šimek et al. (2001). To convert the thymidine incorporation rate to bacterial cell production rate, empirical conversion factors (ECFs) were determined using data from the $<0.8 \mu \mathrm{m}$ treatments. The cell production rate was calculated from the slope of the increase of the natural logarithm of bacterial abundance over time $\left(\mathrm{t}_{0}\right.$ to $\left.t_{48}\right)$. ECFs of $2.48 \times 10^{18}, 4.55 \times 10^{18}, 4.39 \times 10^{18}$, and $3.97 \times 10^{18}$ cells mol ${ }^{-1}$ thymidine were established for treatments $\mathrm{D}, \mathrm{D} \rightarrow \mathrm{M}, \mathrm{M}$, and $\mathrm{M} \rightarrow \mathrm{D}$, respectively.

FISH and microautoradiography. Catalyzed reporter deposition (CARD)-FISH and microautoradiography (Teira et al. 2004) were used for bacterial genotypic identification and analysis of active leucine incorporation. Briefly, samples of $5 \mathrm{ml}$ were incubated with L- $\left[{ }^{3} \mathrm{H}\right]$-leucine, Leu+ (final concentration $20 \mathrm{nmol}$ $\mathrm{l}^{-1}$; specific activity $6.4 \mathrm{TBq} \mathrm{mmol}^{-1}$; MP Biomedicals) for $2 \mathrm{~h}$ at in situ temperature in darkness, preserved in formaldehyde (final concentration $2 \%$ ), and filtered through $0.2 \mu \mathrm{m}$ polycarbonate filters (Poretics; details in Horňák et al. 2006). Prefiltration through a $30 \mu \mathrm{m}$ filter was used to remove large phytoplankton aggregates from the unfiltered treatments. Filters with bacteria were covered with low melting point agarose, followed by incubations with lysozyme and achromopeptidase (Sekar et al. 2003). Bacteria were hybridized with the horseradish peroxidase-labeled probes EUB338 I-III (targeting most Bacteria [EUB]), BET42a (targeting Betaproteobacteria [BET]), GAM42a (targeting Gammaproteobacteria [GAM]), RBT065 (targeting the R-BT065 subcluster [R-BT] of the Rhodoferax sp. BAL47 lineage [also termed the beta I clade]), CF319a (targeting the SphingobacteriaFlavobacteria lineage [SF] of Bacteroidetes), and HGC69a, targeting Actinobacteria (Sekar et al. 2003).
Subsequently, the filters were transferred onto the slides coated with the autoradiography emulsion (NTB, Kodak). After 24 to $48 \mathrm{~h}$ of exposure, the cells were stained with DAPI (final concentration $1 \mu \mathrm{g} \mathrm{ml}^{-1}$ ). The relative abundances of hybridized cells were determined by epifluorescence microscopy (PROVIS AX-70, Olympus). Bacteria incorporating leucine were surrounded by black silver grains. At least 500 DAPIstained cells were counted per sample.

Protistan grazing and abundance. Protistan grazing on bacterioplankton was estimated with short-time uptake experiments (details in Šimek et al. 2001) with fluorescently labeled bacteria (FLB; Sherr \& Sherr 1993) prepared from the Římov reservoir water (details in Šimek \& Straškrabová 1992). FLB uptake rates were enumerated in all $<5 \mu \mathrm{m}$ and unfiltered treatments at $t_{0}, t_{48}$, and $t_{96}$. FLB tracer accounted for 10 to $15 \%$ of natural bacterial abundance. Subsamples of 5 to $20 \mathrm{ml}$ were stained with DAPI, filtered through $1 \mu \mathrm{m}$ black filters (Poretics), and enumerated via epifluorescence microscopy. At least $100 \mathrm{HNF}$ and 50 ciliates (unfiltered treatment only) were inspected per sample. To determine the total grazing rate, average FLB uptake rates of HNF and ciliates were multiplied by their abundances.

Doubling times. In the grazer-free $<0.8 \mu \mathrm{m}$ treatments, increases in absolute numbers of total bacteria as well as of different identified bacterial groups (BET, R-BT, SF, GAM) were used to calculate the bulk- as well as the group-specific net growth rates (details in Šimek et al. 2006). Growth rates were calculated during the fastest phase of bacterial exponential growth ( $t_{0}$ to $t_{48}$ or $t_{48}$ to $t_{96}$ ) and expressed as doubling times.

Viral abundance. At $t_{96}$, samples of $1 \mathrm{ml}$ for abundances of virus-like particles (VLPs) were fixed with glutaraldehyde (final concentration $0.5 \%$ ), frozen in liquid nitrogen, and stored at $-80^{\circ} \mathrm{C}$. After thawing, samples were diluted $10 \times$ in TE-buffer, stained with SybrGreen I (final concentration $5 \mu \mathrm{M}$, Molecular Probes), heated at $80^{\circ} \mathrm{C}$ for $10 \mathrm{~min}$ in the dark, and analyzed by flow cytometry (Brussaard 2004).

Zooplankton composition. At $t_{0}$, zooplankton was concentrated from $\sim 51$ collected at Stns Dam and Middle, preserved with formaldehyde (final concentration $4 \%$ ), and quantified by direct microscopic counting of several subsamples (McCauley 1984). At $t_{96}$, the same procedure was applied to analyze the zooplankton composition in the remaining water $(600$ to $800 \mathrm{ml})$ in the unfiltered dialysis bag treatments.

Statistical analysis. Data on relative abundances (as $\%$ of DAPI-stained cells) and fractions of cells incorporating leucine (as \% of hybridized cells) of bacterial groups were normalized by arcsine transformation. A 2 -way ANOVA, using replicate data $(n=2)$ for every sample, was applied to test the effects of size-fraction- 
ation $(<0.8 \mu \mathrm{m},<5 \mu \mathrm{m}$, unfiltered) and longitudinal transfer ( $D$ versus $D \rightarrow M$, and $M$ versus $M \rightarrow D$ ) on the relative abundances and fractions of cells incorporating leucine. We compared (1) treatments D and $\mathrm{M}$ at $\mathrm{t}_{96}$ versus $D$ and $M$ at $t_{0}$, and (2) treatments $D \rightarrow M$ versus $D$, and $M \rightarrow D$ versus $M$ at $t_{96}$, respectively. Significant ANOVAs were followed by Bonferroni tests applied to pair-wise comparisons of differences in relative abundances and fractions of cells incorporating leucine of bacterial groups. All statistics were performed using GraphPad Prism (GraphPad Software).

\section{RESULTS}

\section{Temperature, phosphorus, and chl a}

Water temperature at a depth of $0.5 \mathrm{~m}$ varied from 19.5 to $24.5^{\circ} \mathrm{C}$ at both stations. Concentrations of TP and DRP in the reservoir water samples were markedly higher at Stn Middle compared to Stn Dam over the duration of the experiment (Table 1). TP and DRP concentrations inside the dialysis bags were also higher at Stn Middle at $t_{96}$ with increasing concentrations from $<0.8 \mu \mathrm{m}$ to unfiltered $\mathrm{M}$ and $\mathrm{M} \rightarrow \mathrm{D}$ treatments (Table 1 ).

Table 1. Concentrations of total phosphorus (TP) and dissolved reactive phosphorus (DRP) in natural samples at Stns Dam and Middle at $t_{0}$ and $t_{96}$, and in $<0.8 \mu \mathrm{m},<5 \mu \mathrm{m}$, and unfiltered $\mathrm{D}, \mathrm{D} \rightarrow \mathrm{M}, \mathrm{M}$, and $\mathrm{M} \rightarrow \mathrm{D}$ dialysis bag treatments at $\mathrm{t}_{96}$

\begin{tabular}{|c|c|c|}
\hline & $\begin{array}{c}\mathrm{TP} \\
\left(\mu \mathrm{M} \mathrm{l}^{-1}\right)\end{array}$ & $\begin{array}{c}\mathrm{DRP} \\
\left(\mathrm{nM} \mathrm{l}^{-1}\right)\end{array}$ \\
\hline \multicolumn{3}{|c|}{ Natural samples } \\
\hline \multicolumn{3}{|c|}{ Start $-\mathrm{t}_{0}$} \\
\hline Dam & 0.34 & 54.9 \\
\hline Middle & 1.25 & 132.4 \\
\hline \multicolumn{3}{|l|}{ End $-t_{96}$} \\
\hline Dam & 0.97 & 77.5 \\
\hline Middle & 2.87 & 371.3 \\
\hline \multicolumn{3}{|l|}{ Treatments } \\
\hline \multicolumn{3}{|l|}{$\mathrm{D}-\mathrm{t}_{96}$} \\
\hline$<0.8 \mu \mathrm{m}$ & 0.62 & 12.9 \\
\hline$<5 \mu \mathrm{m}$ & 0.63 & 45.2 \\
\hline Unfiltered & 0.69 & 32.3 \\
\hline \multicolumn{3}{|l|}{$\mathrm{D} \rightarrow \mathrm{M}-\mathrm{t}_{96}$} \\
\hline$<0.8 \mu \mathrm{m}$ & 1.13 & 38.7 \\
\hline$<5 \mu \mathrm{m}$ & 0.63 & 45.2 \\
\hline Unfiltered & 0.79 & 25.8 \\
\hline \multicolumn{3}{|l|}{$M-t_{96}$} \\
\hline$<0.8 \mu \mathrm{m}$ & 0.73 & 42 \\
\hline$<5 \mu \mathrm{m}$ & 1.19 & 54.9 \\
\hline Unfiltered & 2.79 & 119.5 \\
\hline \multicolumn{3}{|l|}{$\mathrm{M} \rightarrow \mathrm{D}-\mathrm{t}_{96}$} \\
\hline$<0.8 \mu \mathrm{m}$ & 0.78 & 42 \\
\hline$<5 \mu \mathrm{m}$ & 1.21 & 54.9 \\
\hline Unfiltered & 2.67 & 100.1 \\
\hline
\end{tabular}

Chl a concentrations at Stn Dam varied between 16 and $25 \mu \mathrm{g} \mathrm{l}^{-1}$, whereas elevated chl a concentrations in the range of 52 to $65 \mathrm{~g} \mathrm{l}^{-1}$, corresponding to the bloom event, were found over the course of the experimental period at Stn Middle. Large colonies of Microcystis aeruginosa accounted for $>50 \%$ of the total phytoplankton biomass at Stn Dam and 80 to $90 \%$ at Stn Middle at $t_{96}$.

\section{Bacterial abundance and biomass}

The Bacterioplankton assemblage in the grazer-free $(<0.8 \mu \mathrm{m})$ treatment attained higher abundances at Stn Dam compared to Stn Middle (Fig. 1). Transferring the samples from Stn Dam to Stn Middle (D $\rightarrow$ M treatment) yielded a less pronounced increase in total bacterial numbers, while the opposite transfer $(\mathrm{M} \rightarrow \mathrm{D}$ treatment) induced a clear increase in bacterial numbers (Fig. 1). After $t_{24}$ or $t_{48}$, bacterial abundances in the grazerenhanced $(<5 \mu \mathrm{m})$ and unfiltered treatments were markedly lower compared to respective $<0.8 \mu \mathrm{m}$ treatments (Fig. 1), due to rapid development and grazing activity of HNF (Fig. 2) and partially also ciliates (in unfiltered treatment only, data not shown).

Changes in bacterial biomass closely followed the changes in total bacterial numbers (Fig. 1). Compared to the initial samples, bacterial biomass markedly increased in all grazer-free $(<0.8 \mu \mathrm{m})$ treatments, showing maxima in $\mathrm{D}$ and $\mathrm{M} \rightarrow \mathrm{D}$ treatments (Fig. 1). Bacterial biomass was substantially lower in corresponding $<5 \mu \mathrm{m}$ and unfiltered treatments, especially during $t_{48}$ to $t_{96}$ (Fig. 1).

\section{Bacterial production, HNF abundance, and grazing}

Bacterial production (BP) declined during the first day of incubation, but then continuously increased in all treatments (Fig. 2). BP typically peaked at $t_{96}$, particularly in the $\mathrm{M}$ and $\mathrm{M} \rightarrow \mathrm{D}<5 \mu \mathrm{m}$ and unfiltered treatments. The highest numbers of HNF were observed at $t_{72}$, followed by a marked decline at $t_{96}$ (Fig. 2). Total grazing rates accounted for 4 to $88 \%$ of $\mathrm{BP}$, but in $\mathrm{D}$ and $\mathrm{D} \rightarrow \mathrm{M}<5 \mu \mathrm{m}$, and $\mathrm{D}$ and $\mathrm{M}$ unfiltered treatments temporarily exceeded $B P$ rates at $t_{48}$ (Fig. 2).

\section{Bacterioplankton composition}

Bacterial community composition, as analyzed by CARD-FISH targeting broad phylogenetic groups, differed only slightly between the stations at $t_{0}$ (Figs. 3, 4). Using the mixture of EUB338 I-III probes, 


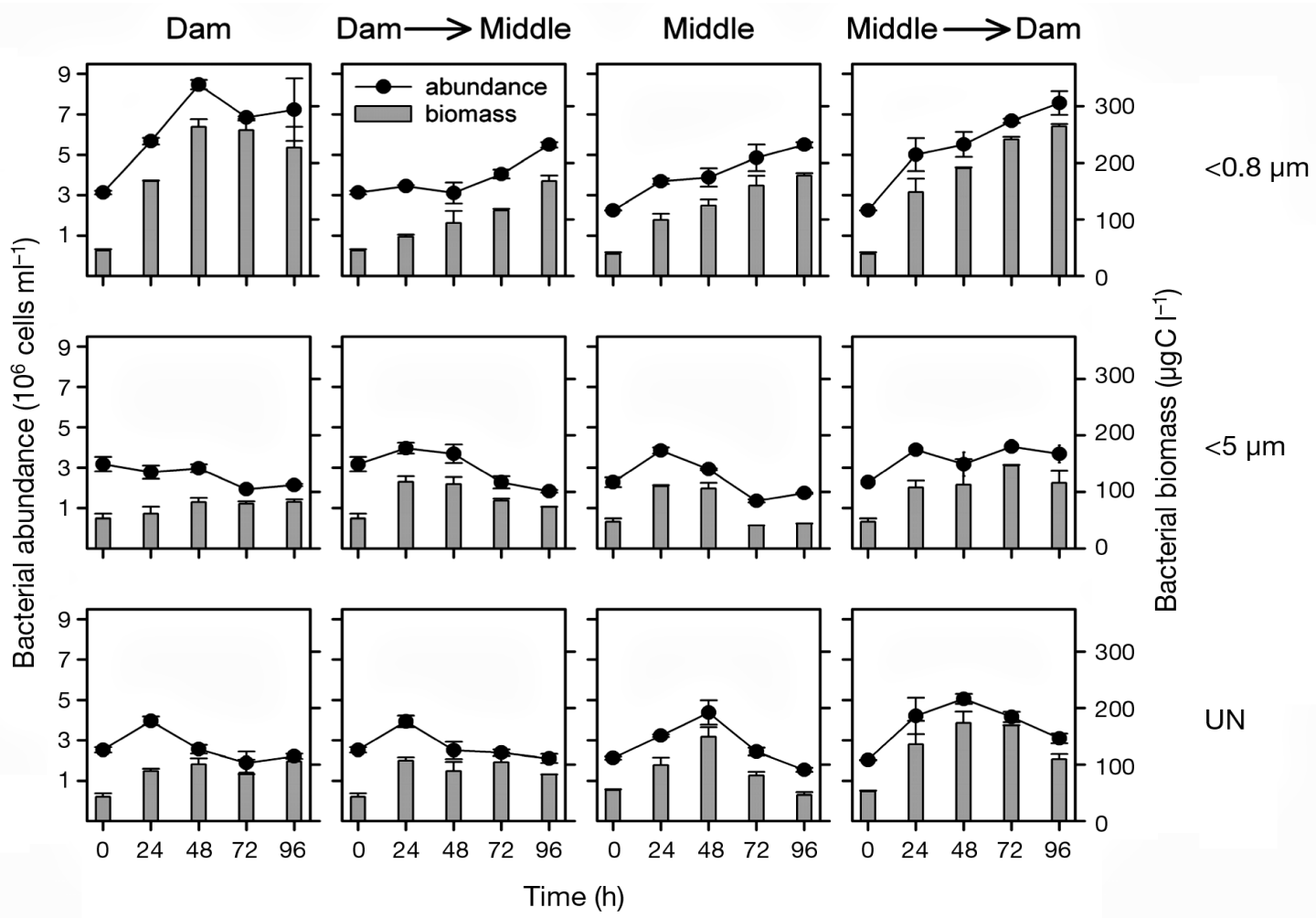

Fig. 1. Changes in bacterial abundance and biomass in $<0.8,<5 \mu \mathrm{m}$, and unfiltered (UN) Dam, Dam $\rightarrow$ Middle, Middle, and Middle $\rightarrow$ Dam treatments $(n=2)$ over the course of the experiment. Error bars $=$ range

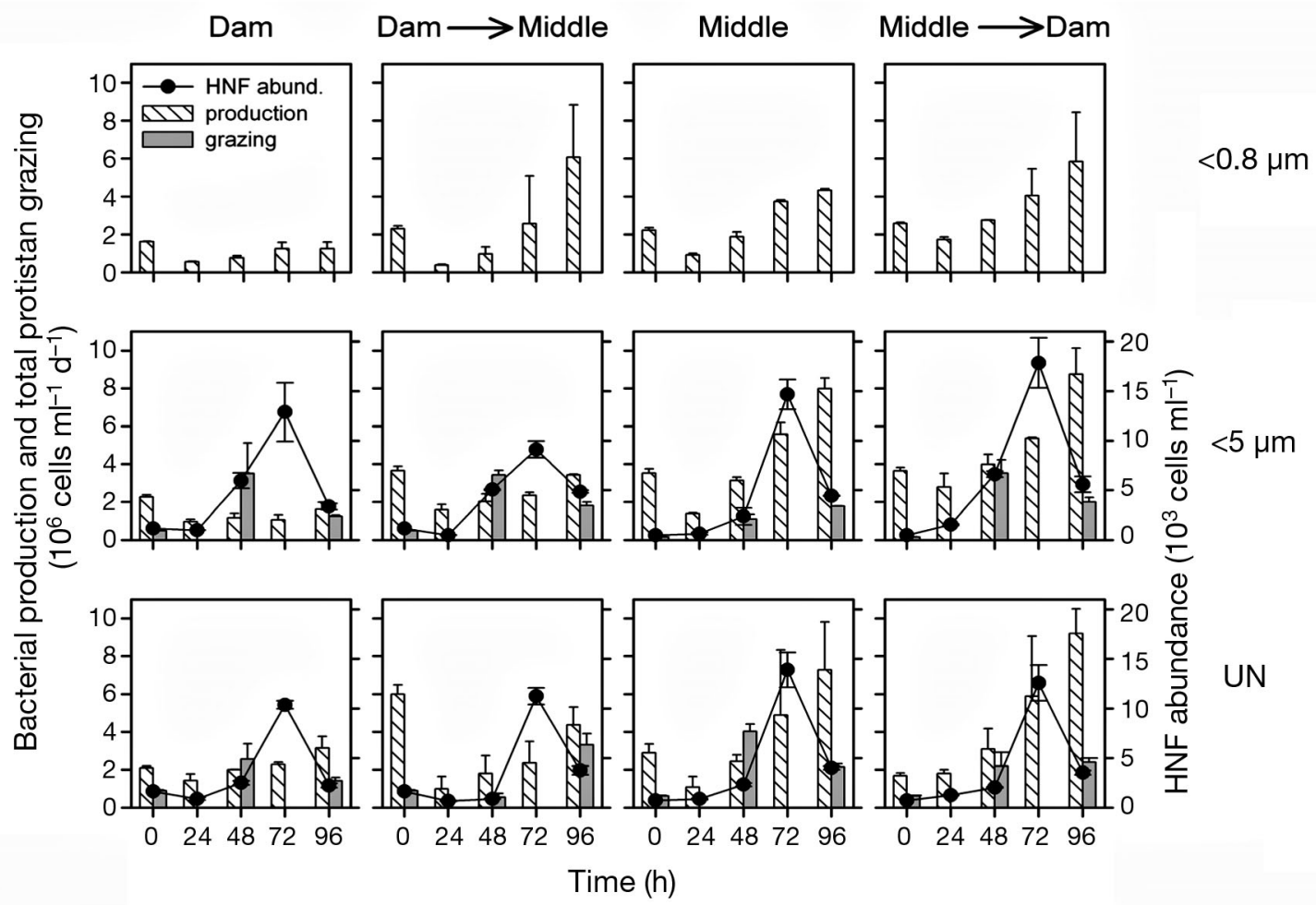

Fig. 2. Bacterial production in $<0.8,<5 \mu \mathrm{m}$, and unfiltered (UN) Dam, Dam $\rightarrow$ Middle, Middle, and Middle $\rightarrow$ Dam treatments $(\mathrm{n}=2$ ), and total protistan grazing and abundance of heterotrophic nanoflagellates (HNF) in $<5 \mu \mathrm{m}$ and UN treatments over the course of the experiment. Error bars = range 

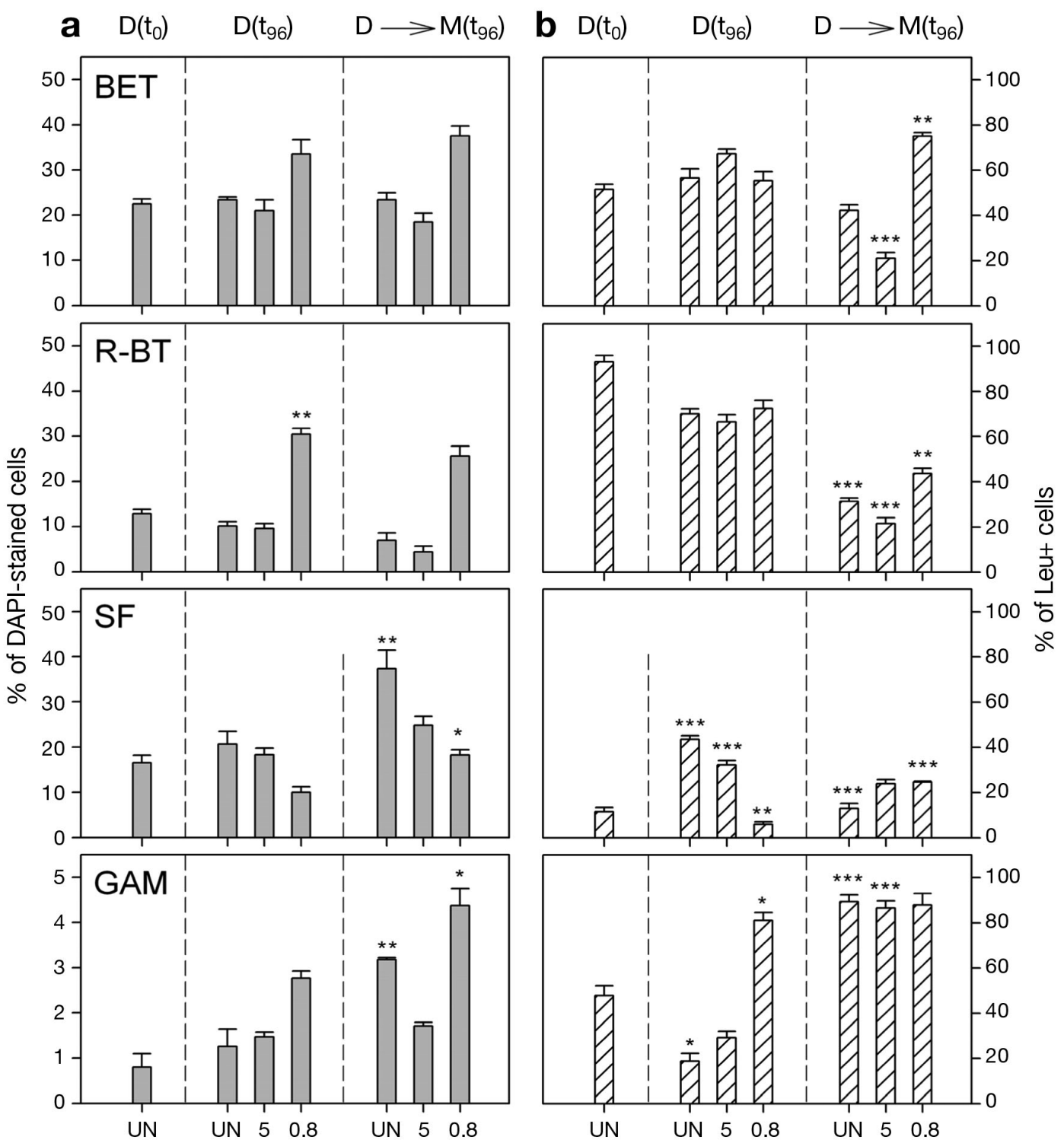

Fig. 3. Relative abundances (a) of DAPI-stained cells (\% total bacterial abundances) and (b) of cells incorporating leucine (Leu+ cells as \% of hybridized cells) of Betaproteobacteria (BET), R-BT065 bacteria (R-BT), Sphingobacteria-Flavobacteria (SF), and Gammaproteobacteria (GAM) at Stn Dam (D) at $t_{0}$ in unfiltered (UN) samples, and at Stn Dam and samples transferred from Stn Dam to Stn Middle $(\mathrm{D} \rightarrow \mathrm{M})$ at $\mathrm{t}_{96}$ in $\mathrm{UN},<5 \mu \mathrm{m}(5)$, and $<0.8 \mu \mathrm{m}(0.8)$ treatments. $\mathrm{n}=2$, error bars = range. Asterisks above bars either indicate (1) that treatments $D\left(t_{96}\right)$ were different from $D\left(t_{0}\right)$ or (2) that treatments $D \rightarrow M\left(t_{96}\right)$ were different from the respective treatment type $(\mathrm{UN}, 5,0.8)$ in the $\mathrm{D}\left(\mathrm{t}_{96}\right)$ sample. ${ }^{*} \mathrm{p}<0.05,{ }^{* *} \mathrm{p}<0.01,{ }^{* * *} \mathrm{p}<0.001$

we detected 65 to $78 \%$ of total DAPI-stained bacteria in all treatments (data not shown). In all treatments, Actinobacteria comprised only $\sim 1 \%$ of total DAPIcounts (data not shown). At $t_{96}$, the bacterial assemblage was dominated at both stations by BET, accounting for 18 to $38 \%$ of DAPI-stained bacteria (Figs. 3, 4). BET dominated particularly in the $<0.8 \mu \mathrm{m}$ treatments ( 34 to $38 \%$ at $t_{96}$ ), while it consistently accounted for lower proportions in the unfiltered and $<5 \mu \mathrm{m}$ treatments (18 to $32 \%$ ). R-BT comprised 5 to $30 \%$ of DAPIstained cells (Figs. 3,4) and followed the pattern of
BET. R-BT bacteria represented the vast majority of BET (57 to $94 \%$ ), except for the unfiltered and $<5 \mu \mathrm{m}$ $\mathrm{M}$ and $\mathrm{D} \rightarrow \mathrm{M}$ treatments at $\mathrm{t}_{96}$ (24 to $40 \%$ ). SF made up 9 to $38 \%$ of the total bacterial community and became the most abundant group in all unfiltered and $<5 \mu \mathrm{m}$ treatments at $t_{96}(25$ to $38 \%$ ) except for the D treatment (Figs. 3, 4). SF represented considerably lower proportions $\left(9\right.$ to $18 \%$ ) in all $<0.8 \mu \mathrm{m}$ treatments at $t_{96}$. In all treatments, GAM accounted for 1 to $4 \%$ (Figs. 3, 4), with the highest percentages ( 3 to $4 \%$ ) found in all $<0.8 \mu \mathrm{m}$ treatments at $t_{96}$. 

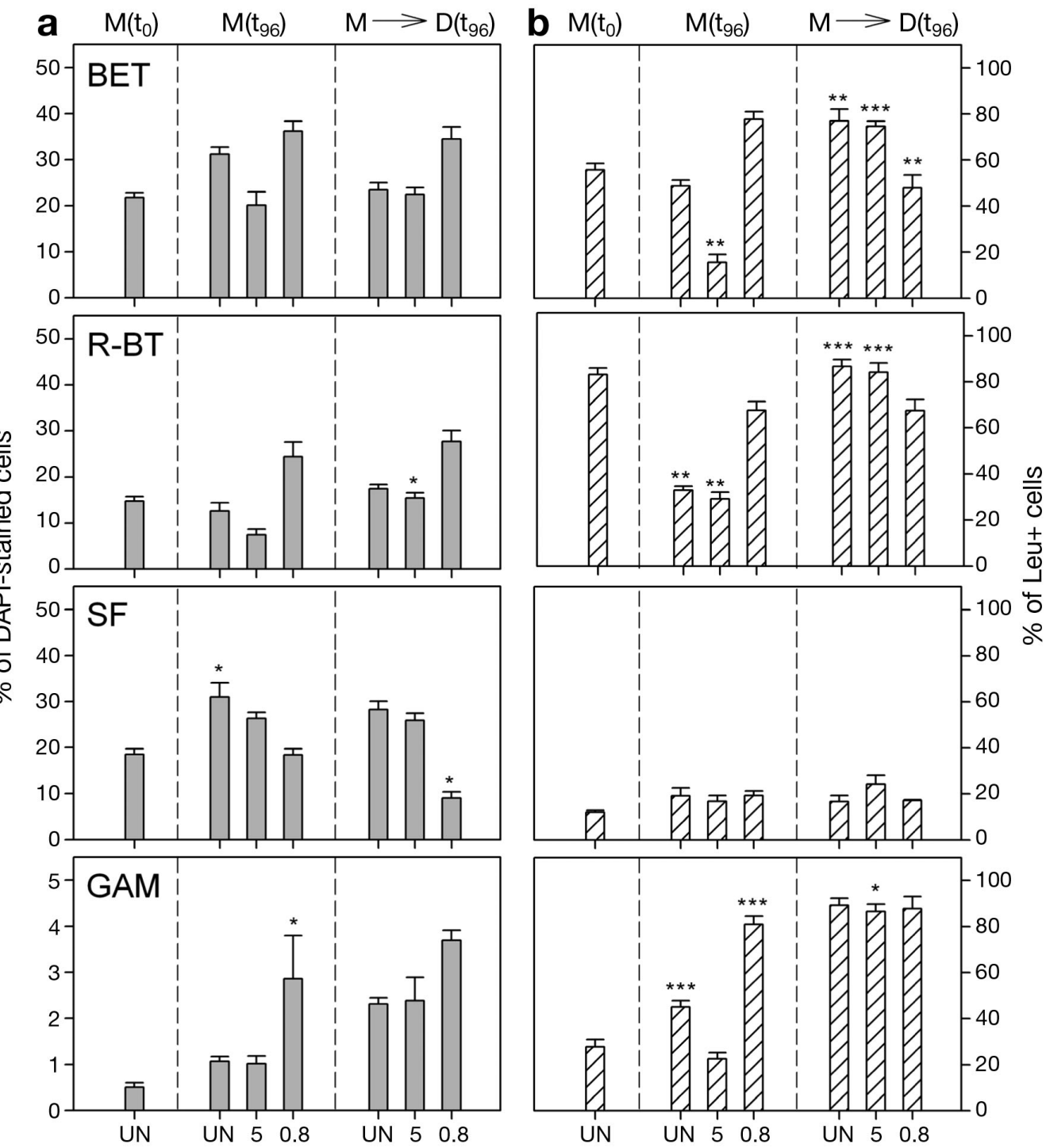

Fig. 4. Relative abundances (a) of DAPI-stained cells (\% total bacterial abundances) and (b) of cells incorporating leucine (Leu+ cells as \% of hybridized cells) of Betaproteobacteria (BET), R-BT065 bacteria (R-BT), Sphingobacteria-Flavobacteria (SF), and Gammaproteobacteria (GAM) at Stn Middle at $t_{0}$ in unfiltered (UN) samples, and at Stn Middle and samples transferred from Stn Middle to Stn Dam at $t_{96}$ in UN, $<5 \mu \mathrm{m}(5)$, and $<0.8 \mu \mathrm{m}(0.8)$ treatments. $\mathrm{n}=2$, error bars = range. Asterisks above bars either indicate (1) that treatments $\mathrm{M}\left(\mathrm{t}_{96}\right)$ were different from $\mathrm{M}\left(\mathrm{t}_{0}\right)$ or $(2)$ that treatments $\mathrm{M} \rightarrow \mathrm{D}\left(\mathrm{t}_{96}\right)$ were different from the respective treatment type (UN, $5,0.8)$ in the $\mathrm{M}\left(\mathrm{t}_{96}\right)$ sample. ${ }^{*} \mathrm{p}<0.05,{ }^{* *} \mathrm{p}<0.01,{ }^{* * *} \mathrm{p}<0.001$

\section{Leucine incorporation}

Between 52 and $56 \%$ of total BET incorporated ${ }^{3} \mathrm{H}$ leucine (Leu+) at $t_{0}$ (Figs. 3, 4). Fractions of Leu+ BET at $t_{96}$ were significantly lower in the unfiltered and $<5 \mu \mathrm{m} \mathrm{D} \rightarrow \mathrm{M}$ treatments (21 to $42 \%$ ) compared to the unfiltered and $<5 \mu \mathrm{m}$ D treatments (57 to $67 \%$, Fig. 3). In contrast, the opposite was true for the $\mathrm{M} \rightarrow \mathrm{D}$ (75 to $77 \%$ ) and $M$ treatments (15 to $38 \%$, Fig. 4). Fractions of Leu+ R-BT bacteria followed the trends of BET and usually exhibited higher proportions of Leu+ cells than BET (Figs. 3, 4). The SF group typically showed the lowest fractions of Leu+ cells (6 to $44 \%$ ), with no clear trend in different treatments (Figs. 3,4). In contrast to BET and R-BT bacteria, fractions of Leu+ GAM increased in the unfiltered and $<5 \mu \mathrm{m} \mathrm{D} \rightarrow \mathrm{M}$ treatments (87 to $89 \%$, Fig. 3 ) at $t_{96}$ and remained very high in all $<0.8 \mu \mathrm{m}$ treatments (81 to $91 \%$, Figs. 3,4).

\section{Doubling times}

Transferring the treatments upstream $(\mathrm{D} \rightarrow \mathrm{M})$ yielded longer doubling times of all bacterial groups 
Table 2. Net doubling times of total bacterioplankton, Betaproteobacteria (BET) the R-BT065 cluster (R-BT), Sphingobacteria-Flavobacteria (SF), and Gammaproteobacteria (GAM) in the $<0.8 \mu \mathrm{m} D, D \rightarrow M, M$, and $\mathrm{M} \rightarrow \mathrm{D}$ treatments. $\mathrm{n}=2 ; \pm$ range is shown

\begin{tabular}{|lcccc|}
\hline & \multicolumn{4}{c|}{ Net doubling time (h) } \\
& $\mathrm{D}$ & $\mathrm{D} \rightarrow \mathrm{M}$ & $\mathrm{M}$ & $\mathrm{M} \rightarrow \mathrm{D}$ \\
\hline Bacterioplankton & $33.4 \pm 0.02^{\mathrm{a}}$ & $64 \pm 21^{\mathrm{b}}$ & $65.4 \pm 15.3^{\mathrm{a}}$ & $37.8 \pm 4.5^{\mathrm{a}}$ \\
$\mathrm{BET}$ & $31.7 \pm 0.7^{\mathrm{a}}$ & $34.5 \pm 4.8^{\mathrm{b}}$ & $34.8 \pm 3.8^{\mathrm{a}}$ & $32.9 \pm 14.2^{\mathrm{a}}$ \\
$\mathrm{R}-\mathrm{BT}$ & $14.1 \pm 1.7^{\mathrm{a}}$ & $35.1 \pm 11.8^{\mathrm{b}}$ & $22.1 \pm 5.8^{\mathrm{a}}$ & $23.5 \pm 7.1^{\mathrm{a}}$ \\
$\mathrm{SF}$ & $45.5 \pm 1.8^{\mathrm{a}}$ & $69.5 \pm 25.9^{\mathrm{b}}$ & $61.8 \pm 14.5^{\mathrm{b}}$ & $91.8 \pm 2.5^{\mathrm{a}}$ \\
$\mathrm{GAM}$ & $17.4 \pm 0.01^{\mathrm{a}}$ & $30.8 \pm 5.8^{\mathrm{b}}$ & $27.3 \pm 2.8^{\mathrm{a}}$ & $16.3 \pm 0.4^{\mathrm{a}}$ \\
${ }^{\mathrm{a}} \mathrm{t}_{0-48}{ }^{\mathrm{b}}{ }^{\mathrm{b}} \mathrm{t}_{48-96}$ & & & & \\
\hline
\end{tabular}

detected (Table 2). In addition, maximum doubling times in the $<0.8 \mu \mathrm{m} \mathrm{D}$ treatment yielded an interval of $\mathrm{t}_{0}$ to $\mathrm{t}_{48}$, while in the $<0.8 \mu \mathrm{m} \mathrm{D} \rightarrow \mathrm{M}$ treatment doubling times were calculated for $t_{48}$ to $t_{96}$. In contrast, the opposite transfer $(\mathrm{M} \rightarrow \mathrm{D})$ accelerated doubling times of BET, GAM, and total bacterioplankton (Table 2), but doubling time of SF was much longer. Members of GAM and R-BT typically exhibited the shortest doubling times, and the R-BT group usually grew faster than BET (Table 2).

\section{DISCUSSION}

During the course of the experiment, the 2 sites differed mainly in the concentrations of TP, DRP (Table 1), and chl $a$, all of which were markedly higher at Stn Middle. Concentrations of TP in the unfiltered water samples at $t_{96}$ at both stations were fairly similar to those measured inside the dialysis bags of the unfiltered treatments. These findings suggest that dialysis membranes were penetrable to $\mathrm{P}$ over the experimental period and that $\mathrm{P}$ supported growth of enclosed communities. In contrast, concentrations of DRP were obviously lower inside the dialysis membranes compared to surrounding environments at $t_{96}$, particularly at Stn Middle (Table 1). Thus, the equilibrium of DRP concentrations between the enclosed assemblages and ambient environments might have been influenced by the reduced membrane permeability and altered DRP transport rates into the dialysis tubes, or by increased microbial DRP uptake kinetics inside the enclosures (cf. Posch et al. 2007), compared to supply processes driven by passive diffusion. However, temporal changes in bacterial abundance after removing the grazers in the $<0.8 \mu \mathrm{m}$ treatments incubated at Stn Dam indicated no obvious effect of decreased $\mathrm{P}$ availability on bacterial growth.

Transplanting the $<0.8 \mu \mathrm{m}$ treatment to Stn Middle yielded significantly decreased bacterial cell numbers
(Fig. 1) compared to increased BP rates (Fig. 2). It seems that total cell counts did not reflect the changes in BP as measured by the thymidine incorporation method, which is potentially due to the presence of rapidly growing bacteria with multiple genome copies or cells with larger genome size.

As in the eutrophic Římov reservoir, R-BT have also been found in the alpine Gossenköllesee (Pérez \& Sommaruga 2006) and in the oligomesotrophic Piburgersee (Salcher et al. 2006). Commonly, R-BT formed a substantial proportion of total BET. R-BT typically overgrew bacteria of other groups in the absence of predators but became mostly suppressed under enhanced grazing pressure (e.g. Šimek et al. 2005, Salcher et al. 2006). R-BT bacteria also exhibited the highest fractions of Leu+ cells of all bacterial groups examined during the clearwater phase (Horńák et al. 2006). Our data on bacterial composition and fractions of Leu+ cells of individual groups at $t_{0}$ are thus consistent with previous studies.

The fraction of Leu+ R-BT bacteria has been typically found to be stimulated by enhanced protistan grazing (Horňák et al. 2006) or by enrichment with algal-derived DOM (Pérez \& Sommaruga 2006). Instead of changing the cell size and morphology toward grazing-resistant morphotypes, R-BT bacteria override the impacts of predation pressure by their ability to multiply fast (cf. Table 2) and seem to be well adapted to utilization of labile DOM of algal origin. However, in our study, both abundance and fractions of Leu+ R-BT cells markedly decreased in the presence of grazers and when transferred to Stn Middle (Fig. 3), while both parameters markedly increased after the transfer to Stn Dam (Fig. 4). It is likely that simultaneous effects of enhanced protozoan grazing and the massive cyanobacterial bloom suppressed the development of R-BT bacteria at Stn Middle.

Fractions of Leu+ SF cells were frequently 20\% (Figs. 3, 4). Members of the SF group seem to be more efficient in the uptake of high molecular weight compounds (Cottrell \& Kirchman 2000). Leucine, commonly used as a general indicator for growth and metabolic activity measurements, thus may not be the most appropriate type of substrate for SF bacteria. Percentages of SF increased in all treatments at $t_{96}$ when transferred to Stn Middle (Fig. 3). It seems that under temporarily increased phytoplankton biomass related to the $M$. aeruginosa bloom, the SF group may dominate the bacterial community, although it typically accounts for 10 to $15 \%$ in the Římov reservoir. The 
fraction of Leu+ GAM was clearly favored by the upstream transfer (Fig. 3), likely profiting from the increased availability of resources. Although GAM exhibited the opposite trend in the fraction of Leu+ cells than the 2 most prominent groups (BET and SF), GAM accounted for only 1 to $4 \%$ of total abundance, and thus it could hardly change the overall negative response of the entire bacterial community subjected to the Microcystis bloom.

Both transfers of the treatments along the longitudinal axis of the reservoir also had distinctly different impacts on doubling times of bulk bacterioplankton and of individual bacterial groups (Table 2). In the treatments incubated at Stn Dam, doubling times of total bacterioplankton and of the probe-defined subgroups fell fairly well into the range of group-specific doubling times observed in 8 manipulation experiments conducted in the Římov reservoir (Šimek et al. 2006). After transferring the treatments to the Microcystis-rich Stn Middle, however, doubling times of all bacterial groups were substantially prolonged (Table 2). In addition, pronounced increases in total bacterial numbers occurred from $t_{48}$ to $t_{96}$, thus reflecting the suppressing effect of the upstream transfer. In contrast, in the treatments transferred to Stn Dam, doubling times of GAM and total bacteria were shorter, and members of the BET and R-BT groups showed comparable doubling times to those incubated in situ, except for the SF group (Table 2). These findings support the evidence of the possible negative effect of cyanobacteria on bacterial development and point to the possible recovery of the bacterial assemblage after transferring to Stn Dam, which was less affected by Microcystis.

In this study, we focused almost exclusively on abundance and fractions of Leu+ cells of free-living bacterioplankton. However, in the unfiltered treatments at $t_{0}$,
5.6 and $20.8 \%$ of DAPI-stained bacteria were associated with phytoplankton in Stns Dam and Middle, respectively. The presence of these aggregates likely underestimated bacterial abundances, either because of difficult microscopic enumeration or because of complete elimination of the large particles in the $<0.8$ and $<5 \mu \mathrm{m}$ treatments. Additionally, prefiltration through a $30 \mu \mathrm{m}$ filter used in all unfiltered treatments before the samples for CARD-FISH and microautoradiography techniques were processed might partially exclude these algal-associated bacteria from the analyses. Nevertheless, the vast majority of total bacteria (78 to $94 \%$ ) were free-living cells, easily accessible to analyses.

We did not quantify the impact of viruses in our study, although this factor may significantly contribute to the specific removal of bacteria (e.g. Weinbauer \& Höfle 1998). At $t_{96}$, abundances of VLPs ranged from 1 to $3.5 \times 10^{8} \mathrm{ml}^{-1}$ in all treatments at both stations. Interestingly, ratios between abundance of VLPs and bacterial abundance were stable in all $<0.8 \mu \mathrm{m}$ treatments (18 to 23), while they were significantly higher in $<5 \mu \mathrm{m}$ and unfiltered treatments (53 to 188), indicating increased viral activity in the presence of grazers (Weinbauer et al. 2003). Although VLP abundances were similar at both stations, the presence of cyanobacteria-related viruses was expected at Stn Middle.

The most important groups of zooplankton likely preying on protists in the unfiltered treatments were filter-feeding cladocerans (Daphnia galeata, Diaphanosoma brachyurum), copepods, and various rotifers (Table 3). Although our experimental setup using the dialysis bag enclosures might discriminate against certain zooplankton species, we did not observe any marked differences in zooplankton composition between the enclosures and initial reservoir sam-

Table 3. Zooplankton abundances (ind. $\mathrm{l}^{-1}$ ) at Stns Dam and Middle at the beginning of the experiment in reservoir water and at the end of the experiment in different unfiltered treatments (UN). Only those zooplankton species or groups with an abundance of $>1$ ind. $\mathrm{l}^{-1}$ are shown

\begin{tabular}{|c|c|c|c|c|c|c|}
\hline & \multirow{2}{*}{$\begin{array}{c}\text { Stn Dam } \\
\mathrm{t}_{0}\end{array}$} & \multicolumn{2}{|c|}{$\mathrm{UN}$ treatment $\mathrm{t}_{96}$} & \multirow{2}{*}{$\begin{array}{c}\text { Stn Middle } \\
\mathrm{t}_{0}\end{array}$} & \multicolumn{2}{|c|}{$\mathrm{UN}$ treatment $\mathrm{t}_{96}$} \\
\hline & & $\mathrm{D}$ & $\mathrm{D} \rightarrow \mathrm{M}$ & & M & $\mathrm{M} \rightarrow \mathrm{D}$ \\
\hline Daphnia galeata & 2 & 6 & 5 & 15 & 11 & 14 \\
\hline Diaphanosoma brachyurum & 41 & 34 & 52 & 61 & 75 & 39 \\
\hline Eudiaptomus gracilis, adults & 1 & 3 & 1 & 4 & 1 & 1 \\
\hline Eudiaptomus gracilis, copepodites & 10 & 3 & 2 & 8 & 4 & 3 \\
\hline Adults of cyclops ${ }^{\mathrm{a}}$ & 3 & 6 & 3 & 4 & 11 & 13 \\
\hline Copepodites of cyclops & 17 & 18 & 13 & 10 & 8 & 5 \\
\hline Total nauplii & 59 & 7 & 3 & 60 & 25 & 19 \\
\hline Rotifers $^{\mathrm{b}}$ & 152 & 141 & 170 & 196 & 241 & 186 \\
\hline
\end{tabular}


ples over the experimental period, suggesting comparable levels of zooplankton grazing in these treatments.

Potential cyanobacterial effects on bacteria may also be related to the release of toxic MCs and other compounds (Casamatta \& Wickstrom 2000). Dissolved MCs have been commonly found in many reservoirs of the Czech Republic, mostly in the range of 2 to $20 \mu \mathrm{g} \mathrm{l}^{-1}$, and Microcystis spp. were recognized as the most important taxa producing MCs (e.g. Bláha \& Maršálek 2003). In the Římov reservoir, 3 to $5 \mu \mathrm{g}$ of dissolved $\mathrm{MCs}^{-1}$ were found at Stn Dam just after the experiment (Znachor et al. 2006). Free MCs may, due to their small size $(\sim 1 \mathrm{kDa})$, easily penetrate through dialysis membranes and directly affect the enclosed bacterioplankton community (e.g. the fractions of metabolically active cells; K. Horňák unpubl. data) subjected to these supposedly toxic compounds.

Some members of the Alphaproteobacteria (ALF) belonging to the microcystin-degrading bacteria have often been found in the mucilage of Microcystis spp. (e.g. Maruyama et al. 2003). These bacteria may thus profit in the presence of a Microcystis bloom. We did not determine the proportions of ALF in our study, since they typically account for a negligible proportion in the total community in the Rímov reservoir, likely being below the detection limit of CARD-FISH. Moreover, BET and SF groups covered the vast majority of total free-living bacteria determined with the EUB338 I-III probe mixture (EUB). Although the fractions of EUB cells (65 to $78 \%$ of total DAPI-stained bacteria) were in the range of values repeatedly reported for the Římov reservoir (e.g. Šimek et al. 2006), we could have underestimated the real abundances of hybridized cells likely due to the presence of the tiny detrital particles, unspecifically stained by DAPI, occurring particularly at Stn Middle.

In summary, the combination of environmental conditions related to the presence of the Microcystis aeruginosa bloom at Stn Middle negatively affected total bacterial cell numbers and biomass as well as doubling times of bulk bacterioplankton and of individual genotypic groups, while the treatments incubated at the Microcystis-poor Stn Dam revealed the opposite trends. In comparison to a previous study conducted in the Římov reservoir during the clearwater phase (Hornák et al. 2006), both the abundance and fractions of Leu+ Betaproteobacteria and of its RBT065 cluster, typically accounting for the majority of total bacteria, were strongly suppressed by the presence of grazers and the Microcystis bloom. In contrast, members of the Sphingobacteria-Flavobacteria lineage numerically dominated the bacterial community under these specific conditions. The fraction of Leu+ Gammaproteobacteria was stimulated by the upstream transfer to the P-rich Stn Middle, but it comprised only very small proportions of the total community. Our study thus suggested group-specific responses of bacteria to the temporary cyanobacterial bloom event.

Acknowledgements. We thank J. Nedoma for bacterial production measurements and M.G. Weinbauer for viral analysis. We also thank P. Znachor for data on the phytoplankton composition, J. Seda for zooplankton composition, and R. Malá, S. Smrčková, and M. Štojdlová for technical help. J. Pernthaler and 3 anonymous reviewers are acknowledged for their valuable comments on an earlier version of the manuscript. The study was supported by research grants 206/08/0015 and 206/05/0007 awarded to K. Š. from the Czech Science Foundation, by the projects 1QS600170504, AVOZ 60170517 and partly by project MSM 6007665801 from the Academy of Sciences of the Czech Republic.

\section{LITERATURE CITED}

Alonso C, Pernthaler J (2006) Concentration-dependent patterns of leucine incorporation by coastal picoplankton. Appl Environ Microbiol 72:2141-2147

Baines SB, Pace ML (1991) The production of dissolved organic matter by phytoplankton and its importance to bacteria: patterns across marine and freshwater systems. Limnol Oceanogr 36:1078-1090

Bláha L, Maršálek B (2003) Contamination of drinking water in the Czech Republic by microcystins. Arch Hydrobiol 158:421-429

Brunberg AK (1999) Contribution of bacteria in the mucilage of Microcystis spp. (Cyanobacteria) to benthic and pelagial bacterial production in a hypereutrophic lake. FEMS Microbiol Ecol 29:13-22

> Brussaard CPD (2004) Optimization of procedures for counting viruses by flow cytometry. Appl Environ Microbiol 70:1506-1513

Casamatta DA, Wickstrom CE (2000) Sensitivity of two disjunct bacterioplankton communities to exudates from the cyanobacterium Microcystis aeruginosa Kützing. Microb Ecol 41:64-73

Chorus I, Bartram J (1999) Toxic cyanobacteria in water: a guide to public health significance, monitoring and management. E\&FN Spon, London

Christoffersen K, Lyck S, Winding A (2002) Microbial activity and community structure during degradation of microcystins. Aquat Microb Ecol 27:125-136

> Codd GA (1995) Cyanobacterial toxins: occurrence, properties and biological significance. Water Sci Technol 32: $149-156$

> Cottrell MT, Kirchman DL (2000) Natural assemblages of marine proteobacteria and members of the CytophagaFlavobacter cluster consuming low- and high-molecularweight dissolved organic matter. Appl Environ Microbiol 66:1692-1697

Eiler A, Bertilsson S (2004) Composition of freshwater bacterial communities associated with cyanobacterial blooms in four Swedish lakes. Environ Microbiol 6:1228-1243

Gobler CJ, Davis TW, Coyne KJ, Boyer GL (2007) Interactive influences of nutrient loading, zooplankton grazing, and microcystin synthetase gene expression on cyanobacterial bloom dynamics in a eutrophic New York lake. Harmful Algae 6:119-133 
Hahn MW, Höfle MG (2001) Grazing of protozoa and its effect on populations of aquatic bacteria. FEMS Microbiol Ecol 35:113-121

Horňák K, Jezbera J, Nedoma J, Gasol JM, Šimek K (2006) Effects of resource availability and bacterivory on leucine incorporation in different groups of freshwater bacterioplankton, assessed using microautoradiography. Aquat Microb Ecol 45:277-289

Jezbera J, Horňák K, Šimek K (2006) Prey selectivity of bacterivorous protists in different size fractions of reservoir water amended with nutrients. Environ Microbiol 8:1330-1339

Jürgens K, Arndt H, Rothhaupth KO (1994) Zooplanktonmediated change of bacterial community structure. Microb Ecol 27:27-42

Kirkwood AE, Nalewajko C, Fulthorpe RR (2006) The effects of cyanobacterial exudates on bacterial growth and biodegradation of organic contaminants. Microb Ecol 51:4-12

Kopáček J, Hejzlar J (1993) Semi-micro determination of total phosphorus in fresh waters with perchloric acid digestion. Int J Environ Anal Chem 53:173-183

Lorenzen CJ (1967) Determination of chlorophyll and phaeopigments: spectrophotometric equation. Limnol Oceanogr 12:343-346

Maruyama T, Kato K, Yokoyama A, Tanaka T, Hiraishi A, Park HD (2003) Dynamics of microcystin-degrading bacteria in mucilage of Microcystis. Microb Ecol 46:279-288

McCauley E (1984) The estimation of the abundance and biomass of zooplankton in samples. In: Downing JA, Rigler FH (eds) A manual on methods for the assessment of secondary productivity in fresh waters. Blackwell, Oxford, p 228-266

Norland S (1993) The relationship between biomass and volume of bacteria. In: Kemp P, Sherr BF, Sherr EB, Cole J (eds) Handbook of methods in aquatic microbial ecology. Lewis, Boca Raton, FL, p 303-308

Pace ML (1988) Bacterial mortality and the fate of bacterial production. Hydrobiologia 159:41-49

Park HD, Iwami C, Watanabe MF, Harada K, Okino K, Hayashi H (1998) Temporal variabilities of the concentrations of intra- and extracellular microcystin and toxic Microcystis species in a hypertrophic lake, Lake Suwa, Japan (1991-1994). Environ Toxicol Water Qual 13:61-72

Pérez MT, Sommaruga R (2006) Differential effect of algaland soil-derived dissolved organic matter on alpine lake bacterial community composition and activity. Limnol Oceanogr 51:2527-2537

Posch T, Mindl B, Horňák K, Jezbera J and others (2007) Biomass reallocation within freshwater bacterioplankton induced by manipulating phosphorus availability and grazing. Aquat Microb Ecol 49:223-232

Riemann B, Søndergaard M (1986) Carbon dynamics in eutrophic, temperate lakes. Elsevier Science Publishers, Amsterdam

Salcher MM, Hofer J, Horňák K, Jezbera J and others (2006) Modulation of predator-prey dynamics by phosphorus availability: growth patterns and survival strategies of bacterial phylogenetic clades. FEMS Microbiol Ecol 60:40-50

Sekar R, Pernthaler A, Pernthaler J, Warnecke F, Posch T, Amann R (2003) An improved protocol for quantification of freshwater Actinobacteria by fluorescence in situ hybridization. Appl Environ Microbiol 69:2928-2935
Sherr EB, Sherr BF (1993) Protistan grazing rates via uptake of fluorescently labeled prey. In: Kemp P, Sherr BF, Sherr EB, Cole J (eds) Handbook of methods in aquatic microbial ecology. Lewis, Boca Raton, FL, p 695-701

Šimek K, Straškrabová V (1992) Bacterioplankton production and protozoan bacterivory in a mesotrophic reservoir. J Plankton Res 14:773-787

Šimek K, Pernthaler J, Weinbauer MG, Horňák K and others (2001) Changes in bacterial community composition and dynamics and viral mortality rates associated with enhanced flagellate grazing in a mesoeutrophic reservoir. Appl Environ Microbiol 67:2723-2733

Šimek K, Horňák K, Jezbera J, Mašín M, Nedoma J, Gasol JM, Schauer M (2005) Influence of top-down and bottomup manipulations on the R-BT065 subcluster of $\beta$-Proteobacteria, an abundant group in bacterioplankton of a freshwater reservoir. Appl Environ Microbiol 71: $2381-2390$

Šimek K, Horňák K, Jezbera J, Nedoma J and others (2006) Maximum growth rates and possible life strategies of different bacterioplankton groups in relation to phosphorus availability in a freshwater reservoir. Environ Microbiol 8:1613-1624

Østensvik, Skulberg OM, Underdal M, Hormazabal V (1998) Antibacterial properties of extracts from selected planktonic freshwater Cyanobacteria - a comparative study of bacterial bioassays. J Appl Microbiol 84:117-1124

Teira E, Reinthaler T, Pernthaler A, Pernthaler J, Herndl GJ (2004) Combining catalyzed reporter deposition-fluorescence in situ hybridization and microautoradiography to detect substrate utilization by bacteria and Archaea in the deep ocean. Appl Environ Microbiol 70:4411-4414

van Hannen EJ, Zwart G, van Agterveld MP, Gons HJ, Ebert J, Laanbroek HJ (1999) Changes in bacterial and eukaryotic community structure after mass lysis of filamentous cyanobacteria associated with viruses. Appl Environ Microbiol 65:795-801

Vila M, Simo R, Kiene RP, Pinhassi J, Gonzalez JA, Moran MA, Pedros-Alio C (2004) Use of microautoradiography combined with fluorescence in situ hybridization to determine dimethylsulfoniopropionate incorporation by marine bacterioplankton taxa. Appl Environ Microbiol 70:4648-4657

Weinbauer MG, Höfle MG (1998) Significance of viral lysis and flagellate grazing as controlling factors of bacterioplankton production in a eutrophic lake. Appl Environ Microbiol 64:431-438

> Weinbauer MG, Christaki U, Nedoma J, Šimek K (2003) Comparing the effects of resource enrichment and grazing on viral production in a meso-eutrophic reservoir. Aquat Microb Ecol 31:137-144

> Worm J, Søndergaard M (1998) Dynamics of heterotrophic bacteria attached to Microcystis spp. (Cyanobacteria). Aquat Microb Ecol 14:19-28

Znachor P, Jurczak T, Komárková J, Jezberová J, Mankiewicz J, Kaštovská K, Zapomělová E (2006) Summer changes in cyanobacterial bloom composition and microcystin concentration in eutrophic Czech reservoirs. Environ Toxicol 21:236-243

Zwart G, Crump BC, Kamst-van Agterveld MP, Hagen F, Han SK (2002) Typical freshwater bacteria: an analysis of available 16S rRNA gene sequences from plankton of lakes and rivers. Aquat Microb Ecol 28:141-155
Editorial responsibility: Ruben Sommaruga, Innsbruck, Austria 